\title{
Repellency of Selected Psidium guajava Cultivars to the Asian Citrus Psyllid, Diaphorina citri
}

José A. A. Silva ${ }^{1}$, David G. Hall ${ }^{2 *}$, Timothy R. Gottwald ${ }^{2}$, Moacir S. Andrade ${ }^{3}$, Walter Maldonado Junior ${ }^{4}$, Rocco T. Alessandro ${ }^{2}$, Stephen L. Lapointe ${ }^{2}$, Eduardo C. Andrade $^{5}$ and Marcos A. Machado ${ }^{1}$

${ }^{1}$ APTA/IAC, Agricultural Secretary of São Paulo State, Caixa Postal 35, Colina, SP, 14770-000, Brazil,

${ }^{2}$ U. S. Department of Agriculture, Agricultural Research Service, 2001 South Rock Road, Fort Pierce, FL 34945, USA

${ }^{3}$ UFSCAR-Federal Universidad of São Carlos-Brazil, Chemical Department

${ }^{4}$ UNESP-University of São Paulo State, Statistic Department

${ }^{5}$ EMBRAPA Cassava and Fruits, Brazil.

* Corresponding author. Tel.: +1 772462 5814; fax: +1 7724625960.

E-mail addresses: - jaalbertosilva@ gmail.com (J.A.A. Silva), David.Hall@ars.usda.gov (D.G. Hall), Tim.Gottwald@ars.usda.gov (T.R. Gottwald), msandrade2003@ gmail.com (M.S.

Andrade),walter@agroestat.com.br (W. Maldonado Jr.), Rocco.Alessandro@ars.usda.gov (R.T. Alessandro), Stephen.Lapointe@ars.usda.gov (S.L. Lapointe), eandrade@cnpmf.embrapa.br (E.C. Andrade), Marcos@ centrodecitricultura.br (M.A. Machado)

Key Words:

Huanglongbing

Citrus greening

Candidatus Liberibacter

guava 
2 Huanglongbing (HLB) is the most devastating disease of citrus worldwide. It is caused by bacteria

3 of the genus 'Candidatus Liberibacter' and transmitted by two psyllid species, the Asian citrus

4 psyllid (ACP) Diaphorina citri, and the African citrus psyllid Trioza erytreae. Considerable

5 research has been conducted toward developing and implementing HLB and ACP management

6 strategies. With respect to ACP control, of interest is that reports indicate guava, Psidium guajava,

7 can be repellent to ACP. We conducted research to further evaluate repellency of guava to ACP. In

8 one set of experiments, guava oil from five Brazilian guava cultivars ('J3', 'Pedro Sato', 'Século

9 XXI', 'Thailand' and 'Paluma') was extracted from leaves (immature and mature) by hydro-

10 distillation in a Clevenger-type apparatus and evaluated for psyllid repellency. In a second set of

11 experiments, repellency of guava leaves to ACP was investigated using leaves (immature and

12 mature) from two guava cultivars in Florida, 'Pink' and 'Thai White'. In each set of experiments,

13 repellency was evaluated by releasing ACP adults into a cage with two large vials, one containing a

14 young flush shoot (= immature leaves) of Murraya exotica (a favored host plant of the psyllid, the

15 flush of which is highly attractive to ACP) and one with $M$. exotica flush and the test material of

16 interest (guava oil, immature guava leaf or mature guava leaf). The adults were free to move

17 throughout the cage and into the vials, and the number of psyllids in each vial was counted after 24

$18 \mathrm{~h}$. The results showed that all guava materials tested had at least some repellency to ACP. Mature

19 leaves tended to have a greater repellent effect than immature leaves. Each of the five oils exhibited

20 repellency. A report in the literature suggested that sulfur compounds associated with guava may be

21 responsible for ACP repellency. Interestingly, the five guava oil extracts we studied were repellent

22 to ACP but none contained any sulfur compounds. Identification of the constituents responsible for

23 repellency could lead to new ACP management tactics.

\section{Introduction}


Huanglongbing (HLB) is a devastating disease of citrus caused by bacteria in the genus

28

29

30

'Candidatus Liberibacter' known to be transmitted by two psyllid species, the Asian citrus psyllid (ACP) Diaphorina citri Kuwayama, and the African citrus psyllid Trioza erytreae (del Guercio) (Bové, 2006; Gottwald, 2010; Hall et al., 2013a). HLB attributed to 'Ca. Liberibacter asiaticus' and vectored by ACP is considered to be Asian in origin and has spread to other citrus growing regions around the world including Brazil and the United States of America (USA). In addition, HLB attributed to ' $\mathrm{Ca}$. Liberibacter americanus' vectored by ACP was discovered in Brazil (Gottwald, 2010). Citrus trees infected by HLB pathogens become unproductive with thinning canopies, juice from the fruit of infected trees develop off-flavors, the disease promotes premature fruit drop, and infected trees may eventually die. The citrus industries in Brazil and USA and other areas where HLB has spread have scrambled to find solutions with little success. In Brazil, citrus growers attempt to manage HLB using a three-tiered approach: only plant new trees that are free of the disease, establish and maintain aggressive insecticide programs for psyllid control, and aggressively find and remove infected trees to reduce inoculum loads. In the USA where HLB is currently jeopardizing the Florida citrus industry, citrus growers initially followed the same three-tiered program, but the high cost of identifying and removing infected trees and reluctance to remove infected trees that were still productive led to most growers abandoning the tree-removal component of this HLB management program (Hall et al., 2013a). Furthermore, aside from the fact that intensive insecticide programs are not sustainable, even the most intensive insecticide programs against ACP have provided little protection against the introduction and spread of HLB in new plantings (Hall et al., 2013b). Solutions to HLB remain desperately needed.

The pursuit of improved management tactics for ACP includes research in the area of chemical ecology searching for attractants and repellents. An attractant could be used for ACP surveillance and possibly for mating disruption. A repellent could be used to drive ACP away from citrus. With respect to attractants, Wenninger et al. (2008) reported behavioral evidence of an ACP sex pheromone, although to-date none have been identified. With respect to ACP repellents, Beattie et 
al. (2006) reported that, in Vietnam, citrus intercropped with guava (Psidium guajava L., plant

54 family Myrtaceae) had a lower incidence of HLB compared to citrus planted alone, possibly due to

55 the presence of volatiles associated with guava that repelled ACP. Since then, a number of research

56 efforts have been made on repellency of guava and other plant species to ACP including Chen et al.

57 (2006); Hall et al. (2008); Onagbola et al. (2011); Rouseff et al. (2008); Gottwald et al. (2010);

58 Zaka et al. (2010); Mann et al. (2012); and Robbins et al. (2012). Gottwald et al. (2014) reported

59 that the Vietnamese guava effect could not be verified in Florida citrus due to problems with

60 nematodes and sensitivity of guava to cold weather. Ultimately, even if guava could be grown in an

61 area, it would likely promote problems with fruit flies in citrus. As an alternative to intercropping

62 guava and citrus, if guava volatiles with repellency to ACP could be identified, it might be possible

63 to use these against ACP without requiring that guava be grown with citrus.

64 The goal of research presented here was to further assess repellency of guava to ACP.

\section{Materials and methods}

67

Two experiments were conducted to assess repellency of guava to ACP. In one experiment, ACP attraction and settling behavior were studied on young flush shoots of orange jasmine in the presence or absence of oil extracts from one of five different guava cultivars. Orange jasmine [Murraya exotica L. (= Murraya paniculata auct. non.)] is a favored host plant of ACP (Hall and Rohrig, 2015). ACP reproduction is dependent on young flush shoots (Husain and Nath, 1927), which are immature or young leaves as described by Hall and Albrigo (2007). In the second experiment, ACP attraction and settling behavior were studied using orange jasmine flush shoots in the presence or absence of guava leaves. 
Essential oils from fresh immature and mature leaves of five guava cultivars were studied, three of red pulp commercially known as 'Paluma', 'Pedro Sato', and 'Século XXI'; one of white pulp

81 identified as 'Thailand'; and one new selection of red pulp identified as ' $\mathrm{J} 3$ ' and considered to have some repellency to the guava psyllid Triozoida limbata (Hemiptera: Triozidae). Young and mature leaves from these cultivars were collected in September 2013 from six-month-old, potted plants propagated by rooting of semi-hardwood cuttings. The essential oils were obtained by hydrodistillation for $3 \mathrm{~h}$ of $50 \mathrm{~g}$ leaf material in $500 \mathrm{~mL}$ water using a Clevenger-type apparatus, adapted according to the method described in British Pharmacopoeia (1980). The volatile compounds were extracted from the distillation water with dichloromethane, dried over anhydrous sodium sulphate and carefully concentrated under $\mathrm{N}_{2}$ to a final volume of $<0.5 \mathrm{~mL}$, and then analysed by gas chromatography / mass spectrometry (GC/MS) using a Shimadzu QP5050A system equipped with J\&W Scientific DB-5 fused silica capillary column (30m x $0.25 \mathrm{~mm}$ i.d. x $0.25 \mu \mathrm{m}$ film thickness); column temperatures were programmed from $60^{\circ} \mathrm{C}$ for $3 \mathrm{~min}$, raised to $150^{\circ} \mathrm{C}$ at $8^{\circ} \mathrm{C} / \mathrm{min}$, isotherm of $5 \mathrm{~min}$, raised to $280^{\circ} \mathrm{C}$ at $12^{\circ} \mathrm{C} / \mathrm{min}$ and isotherm of $5 \mathrm{~min}$. Injector and detector temperatures were $250^{\circ} \mathrm{C}$ and $280^{\circ} \mathrm{C}$, respectively. Helium was used as carrier gas, with flow rate of $1.5 \mathrm{~mL} / \mathrm{min}$, split mode. Injection volume was $1.0 \mu \mathrm{L}$ solution in dichloromethane. The MS were taken at $70 \mathrm{eV}$. Scanning speed was $0.5 \mathrm{scan} / \mathrm{sec}$ from $\mathrm{m} / \mathrm{z} 50$ to 500 . The retention indices were obtained by injecting the $\mathrm{C}_{10}-\mathrm{C}_{29}$ linear hydrocarbon mixture. The percent composition of each component was determined from the area of the component divided by the total area of all components isolated under these conditions. The volatile components were analyzed by GC/MS, and identification was made on the basis of comparison of retention indices as well as by computerized matching of the acquired mass spectra with those stored in the National Institute of Standards and Technology's mass spectral library of the GC/MS data system and other published mass spectra. To test the guava oils for repellency to ACP, $20 \mu \mathrm{g}$ of each guava oil was mixed into $10 \mathrm{~mL}$ of SPLAT ${ }^{\mathrm{TM}}$ (ISCA

103 Technologies, Inc., Riverside, CA), an emulsified wax substrate for slow release of insect semiochemicals (Lapointe et al., 2011). A cotton wick was treated with $1.0 \mathrm{~g}$ of SPLAT containing 
guava oil. Assays were then conducted in which ACP attraction to young flush shoots of orange jasmine with and without a cotton wick containing guava oil was assessed as described below.

ACP attraction to flush in the presence or absence of guava oil was assessed using a behavioral assay described by Hall et al. (2015). Two large vials each containing young flush shoots of orange jasmine (a combined average weight of flush per vial of $0.27 \pm 0.05 \mathrm{~g}$ ) were placed into an assay cage (described below). One vial also received a cotton wick treated with one of the guava oils in SPLAT. In addition to the five guava oil treatments, a sixth treatment was included in which one vial of orange jasmine flush received a cotton wick treated with SPLAT not containing any oil. The assay vials were 25 dram plastic tubes measuring 39 x 85 mm I.D. (diameter $\mathrm{x}$ height) (\#8925, BioQuip Products, Inc., Gardenia, CA) with white snap-on plastic lids. We used a cork borer to cut a $6 \mathrm{~mm}$ diameter hole through each vial's lid. Flush shoots for the assay were excised from potted plants in a greenhouse; the cut end of each flush shoot was slipped into a $1.5 \mathrm{~mL}$ centrifuge tube containing tap water and secured to the tube with Parafilm $\mathrm{M}^{\circledR}$ laboratory film (American National Can, Chicago, IL). Two tubes each with flush were placed into each assay vial, and each tube with flush was held in an upright position in the vial by a plastic support. Each plastic support was the bottom half of one of the small centrifuge tubes, cut in half with the top half discarded and the bottom half hot-glued in an upright position to the inside bottom wall of the vial - a centrifuge tube fitted with a flush shoot in water was slipped down into each plastic support. After the two tubes with flush were placed into a vial, the lid was snapped into place and the exterior clear wall of each vial was covered with white paper to conceal the contents of the vial, thus preventing visual attraction to flush but allowing odors associated with flush to attract ACP into a vial through the lid's hole.

The two assay vials containing shoots with or without guava oil were placed together onto the floor of a cubic cage $(30 \times 30 \times 30 \mathrm{~cm})$, with the vials positioned $10 \mathrm{~cm}$ from each other. The assay cage (Bugdorm-1 insect cage, DP1000, MegaView Science Co., Ltd., Taichung, Taiwan) was screened $\left(24 \times 24\right.$ mesh $\left./ 6.5 \mathrm{~cm}^{2}\right)$ on three sides with three solid sides made of a soft, thin, translucent 
material. A net sleeve through one of the solid sides allowed introduction and removal of the vials.

The cage was placed into an environmental chamber set at $27^{\circ} \mathrm{C}, 24$ h daily illumination (humidity was not controlled but averaged 44\%). Fifty adult ACP ( 10 days old) were aspirated into a small glass vial which was placed onto the floor of the cage at the center of the cage between the two assay vials with flush. The adults were free to exit the small glass vial. The number and gender of adults in each assay vial, and the number and gender of adults found in the cage outside of the assay vials, were determined $24 \mathrm{~h}$ later. The data variable of interest was the percentage of ACP ending up in vials containing guava oil. Each guava oil treatment was studied individually one after another and all treatments were replicated 10 times. For each new replication of each treatment, the position of the assay vial with oil in the cage was reversed; in addition, there were three environmental chambers with the indicated settings, and treatments were systematically rotated among the three chambers.

\subsection{Repellency of guava leaves to adult ACP} were three cage treatments: 1) a cage with two vials each containing orange jasmine flush;2) a cage with one vial containing orange jasmine flush and the second vial containing orange jasmine flush plus a young guava flush shoot; and 3) a cage with one vial containing orange jasmine flush and a second vial containing orange jasmine flush plus an intact mature guava leaf (the cut end of which was secured in a $1.5 \mathrm{ml}$ centrifuge tube containing water). Two guava cultivars were studied, 'Pink' and 'Thai White'. 'Thai White' was a white guava cultivar commonly grown in South 154 Vietnam - although similar in appearance to the Brazilian 'Thailand' cultivar, it was not known if these were genetically the same. For vials containing orange jasmine or guava flush shoots, there 
157 guava leaves, there was an average of $1.80 \pm 0.60 \mathrm{~g}$ of mature leaf tissue per vial. The assay was

158 repeated 16 times for each cultivar, rotating the treatments among the three environmental chambers 159 and switching the position of the vials in each cage. All replications for one cultivar were 160 completed before starting those for the second cultivar.

2.3. Longevity and oviposition of adult ACP confined to guava

Longevity and oviposition activity by ACP on guava in a no-choice setting was investigated using potted plants placed into BugDorm-2 cages (\#2120, 60x60x60cm, MegaView Science Co., Ltd., Taichung, Taiwan). A group of 100 adult ACP ( 10 days old) was placed into a cage with a 'Pink' guava plant, another group of 100 adults was placed into a cage with a 'Thai White' guava plant, and a third group of 100 adults was placed into a cage with Citrus macrophylla Wester ('Alemow'), a citrus plant known to be susceptible to ACP. In addition, a fourth group of 100 adults was placed into an empty cage. The cages were maintained in a greenhouse under ambient conditions and checked daily over 10 days to count numbers of dead ACP and to determine if oviposition occurred.

\subsection{Data analyses}

Data from the studies with guava oil and guava leaves were subjected to analyses of variance (completely randomized design for comparisons among treatments or randomized block design for comparisons within treatments), and mean differences among treatments were investigated using Tukey's studentized range (HSD) test. Percentage data were arcsine-transformed for these analyses

179 (arcsine $\sqrt{x / 100})$. ACP longevity data were logistic-transformed $(\log [\mathrm{x} /(1-\mathrm{x})])$ and subjected to 180 logistic regression to compare survival on guava to survival on citrus. All statistical tests were 181 conducted at the 0.05 level of significance. 


\section{Results and discussion}

Results of the chemical analyses on volatiles associated with oil extracts from the five guava

cultivars are shown in Tables 1 and 2. $\quad \beta$-caryophyllene was identified as a major constituent in oil

from each of the five Brazilian guava cultivars, but in most other respects volatile constituents of the five oils differed substantially. Alquezar García et al. (2011) reported that the components $\beta$ caryophyllene and $\alpha$-copaene have repellency to ACP. However, $\beta$-caryophyllene is common in orange jasmine (Raina et al., 2006; Lv et al., 2013), and ACP is highly attracted to orange jasmine.

The guava oil 'J3' contained a high percentage of limonene, a common compound in Citrus species and reported to be an ACP attractant (Patt and Sétamou, 2010), and $\alpha$-pinene which was not associated with oil from the other cultivars. Co-dominant compounds may be particularly important

with regard to repellency to ACP. Sesquiterpenes were a major constituent of each of the five guava oils, especially in oil from 'Paluma', and oil from cultivar 'J3' was markedly different in that it was the only oil containing a large percentage of monoterpenes (Table 2).

Large percentages of ACP showed responses to odors in the guava oil assays, with from 72 to $79 \%$ of adults (mean of $75 \%$ ) entering and settling in one of the two vials (Table 3 ). There was no preference between the two vials containing orange jasmine flush when no guava oil was present. However, significantly fewer adults entered and settled on flush when guava oil was present. This was true for all five guava cultivars, with from 2 to 4 (mean of 2.7) times more adults ending up in vials without guava oil. For the five guava oil treatments, an average of $54 \%$ of ACP chose the vial with only jasmine flush compared to $21 \%$ choosing the vial with both jasmine flush and guava oil, a reduction of $61 \%$. Zaka et al. (2010) indicated a reduction of $52.7 \%$ in the number of psyllids on citrus leaves when guava foliage was present, and reported that immature and mature leaves showed equal repellent activity.

In the experiments with 'Pink' guava leaves, large percentages of ACP entered and settled in vials (from 68 to $79 \%$ and a mean of $73 \%$ ) (Table 4). There were no significant differences in 
percentages of ACP ending up in the two vials when each contained orange jasmine flush. There

210 were also no significant differences in percentages of ACP ending up in vials when one contained

211 jasmine flush and one contained 'Pink' guava flush, although there tended to be fewer in the vial

212 with guava flush. However, significantly greater percentages of ACP ended up in vials containing

213 jasmine flush when the other vial contained a mature 'Pink' guava leaf, indicating a repellent effect

214 associated with mature leaves.

215 From 73 to $87 \%$ (mean $78 \%$ ) ACP chose and settled in vials during experiments with 'Thai

216 White' guava leaves (Table 5). Similar to the results with 'Pink' guava leaves, there were no

217 significant differences in percentages of ACP ending up in the two vials when each contained

218 orange jasmine flush, and significantly greater percentages of ACP ended up in vials containing

219 orange jasmine flush when the other vial contained a mature 'Thai White' guava leaf. However,

220 unlike the experiments with 'Pink' guava leaves, adult ACP were significantly attracted into vials

221 containing 'Thai White' flush, indicating that flush of this cultivar has an ACP attractant. These

222 results differed from those of Zaka et al. (2010) who reported equal repellent activity when

223 comparing immature and mature guava leaves placed beside a citrus shoot.

224 Analyses of combined data from the experiments with 'Pink' and 'Thai White' guava indicated

225 that both immature and mature leaves of each cultivar were repellent, that mature leaves of 'Thai

226 White' were significantly more repellent than immature leaves, and that repellency to ACP of

227 mature leaves was similar between the two cultivars (Table 6). Gottwald et al. (2014) reported a

228 significant reduction in field infestations of ACP in citrus intercropped with 'Pink' guava but not in

229 citrus intercropped with 'Thai White' guava. Repellency to ACP of any guava cultivar could be

230 positively or negatively affected by a number of abiotic and biotic factors.

231 Nearly $100 \%$ of adult ACP survived over a ten-day period when they were confined to citrus

232 (Fig. 1), and large numbers of eggs were observed on this plant. When adults were confined in a

233 cage without a host plant, 100\% mortality occurred within five days; Hall and McCollum (2011)

234 reported similar longevity when they held adults without a food host. Adult ACP confined to guava 
lived longer than adults held without a host plant; they were often observed in a feeding position on

leaves, and the adults spent most of their time on the guava plants rather than on the floor or sides of the cages. However, $100 \%$ of the ACP confined to 'Thai White' and 'Pink' guava died within nine and ten days, respectively. Logistic regression indicated that ACP longevity was longest on citrus and that longevity of ACP was longer on 'Pink' guava than on 'Thai White' guava (Table 7). These results are agreement with a report by Hall et al. (2008) showing that ACP did not survive for very long when confined to five different guava cultivars in a no-choice situation, with 95 to $100 \%$ mortality occurring within 6 to 9 days. These results indicated that, while guava may have traits that are repellent to ACP and although ACP may be able to sustain itself on guava for at least several days, guava did not appear to be acutely toxic to ACP. No oviposition occurred on guava during the test although young flush leaves were present.

Reports in the literature indicated intercropping guava and citrus can reduce the incidence of

247 HLB in citrus by suppressing infestations of ACP, and a number of research efforts have been made 248 to document this effect by guava on ACP and to discover reasons responsible (Hall et al., 2008; 249 Rouseff et al., 2008; Gottwald et al., 2010; Zaka et al., 2010; Onagbola et al., 2011). The research presented here confirms that guava leaves have repellency to ACP and is the first study to show that 251 extracts of oil from the leaves of five different guava cultivars have repellent activity. One of the 252 cultivars, 'J3', is known to have repellency to Triozoida limbata, a psyllid that causes severe 253 damage to some guava cultivars in Central and South America (Sá and Fernandes 2015).

254 Reasons why guava exhibits repellency to ACP remain unclear. Rouseff et al. (2008) and 255 Onagbola et al. (2011) hypothesized that sulfur compounds associated with guava, particularly 256 dimethyl disulfide, were at least partially responsible. This compound is an insect toxic, defensive 257 volatile produced only by guava leaves with injuries (crumpled or torn). For our studies on guava 258 oil, we chopped leaves and then performed the extractions. We did not detect any sulfur compounds in the oil extracts (hydro-distillation extractions may miss some compounds such as sulfur) thus 
their repellency to ACP was the result of some other volatile (s). We found that both young and mature guava leaves repelled ACP, with mature leaves generally more repellent than young leaves.

Overall based on the results of this project, we conclude that guava does contain traits repellent to ACP, that leaf age plays some role in this repellency, and that there can be at least moderate differences in repellency among different guava cultivars.

\section{Acknowledgments}

We acknowledge and thank the following individuals and institutions for their contributions to this project: Joe Patt, Matt Hentz, Earl Taylor and Anna Sara Hill (ARS-USDA, Fort Pierce, FL, USA); INCT Citros (CNPq and Fapesp), Brazil; UFSCAR-Brazil-Chemical Department; and Josie Salinas (USDA-APHIS-PPQ-CPHST, Edinburg, TX, USA). Mention of a trademark or proprietary product is solely for the purpose of providing specific information and does not constitute a guarantee or warranty of the product by the U.S. Department of Agriculture and does not imply its approval to the exclusion of other products that may also be suitable. USDA is an equal opportunity provider and employer.

References

Alquezar García, B., Rodriguez Baixauli, A., Peris Rodrigo, J., Peña García, L., Enrique, A., Pedreira De Miranda, M., Yamamoto, P.T., Spósito, M.B., Wulff, N.A., Teixeira, D.C., Ayres,

$$
\text { A.J., Noronha N.C., Bento, J.M.S., Parra, J.R.P., 2011. (Patent WO2011050432) Repellent }
$$

Compositions and Genetic Approaches for Controlling Huanglongbing. https://patentscope.wipo.int/search/en/detail.jsf?docId=WO2011050432\&recNum=259\&docAn $=\underline{=B R 2010000353 \& q u e r y S t r i n g}=$ brazil $\& \max R e c=4628$ 
Beattie, G.A.C., Holford, P., Mabberley, D.J., Haigh, A.M., Bayer, R., Broadbent, P., 2006. Aspects and insights of Australia-Asia collaborative research on huanglongbing, p. 47-64. In: Proc. Intl. Wkshp. for the Prevention of Citrus Greening Disease in Severely Infected Areas. Intl. Res. Div., 46 Agriculture Forestry Fisheries Research Council Secretariat, Ministry of Agriculture, Forestry and Fisheries, Tokyo, Japan.

Bové, J.M., 2006. Huanglongbing: A destructive, newly-emerging, century-old disease of citrus. J. Plant Pathol. 88, 7-37.

British Pharmacopoeia, 1980. 11. P.A. HMSO: London.

293 Chen, H., Sheu, M., Wu, C., 2006. Characterization of volatiles in guava (Psidium guajava L. cv. Chung-Shan-Yueh-Pa) fruit from Taiwan. Journal of Food and Drug Analysis, vol, 14, n. 4, p. 398-402.

Gottwald, T.R., 2010. Current epidemiological understanding of citrus huanglongbing. Annu. Rev. Phytopathol. 48, 119-139.

Gottwald, T.R., Hall, D.G., Beattie, G.A.C., Ichinose, K., Nguyen, M.C., Le, Q.D., Bar-, M, Lapointe, S., Stover, E., Parker, P.E., McCollum, G., Hilf, M.E., 2010. Investigations of the effect of guava as a possible tool in the control/management of Huanglongbing. Proceedings, 17th Conference IOCV - Insect-Transmitted Procaryotes. p. 98-109.

Gottwald, T.R., Hall, D.G., Kriss, A.B., Salinas, E.J., Parker, P.E., Beattie, G.A.C., 2014. Orchard and nursery dynamics of the effect of interplanting citrus with guava for huanglongbing, vector, and disease management. Crop Prot. 64, 93-103.

Hall, D.G., Albrigo, L.G., 2007. Estimating the relative abundance of flush shoots in citrus, with implications on monitoring insects associated with flush. HortScience 42: 364-368.

Hall, D.G., McCollum, G., 2011. Survival of adult Asian citrus psyllid on harvested citrus fruit and leaves. Fla. Entomol. 94, 1094-1096.

Hall, D.G., Rohrig, E., 2015. Bionomics of Asian citrus psyllid (Hemiptera: Liviidae) associated with orange jasmine hedges in southeast central Florida, with special reference to biological control by 
Tamarixia radiata. J. Econ. Entomol. 1-10; DOI: http://dx.doi.org/10.1093/jee/tov052.

312 Hall, D.G., Hentz, M.G., Patt, J.M., 2015. Behavioral assay on Asian citrus psyllid attraction to orange jasmine. J. Insect Behavior. (doi:10.1007/s10905-015-9525-1)

314 Hall, D.G., Gottwald, T.R., Nguyen, N.C., Ichinose, K., Le, Q.D., Beattie, G.A.C., Stover, E., 2008.

315 Greenhouse investigations on the effect of guava on infestations of Asian citrus psyllid in 316 grapefruit. Proc. Fla. State Hort. Soc. 121, 104-109.

317 Hall, D.G., Richardson, M.L., Ammar, E., Halbert, S.E., 2013a. Asian citrus psyllid, Diaphorina 318 citri, vector of citrus huanglongbing disease. Entomologia Experimentalis et Applicata 146, $319 \quad 207-223$.

320 Hall, D.G., Gottwald, T.R., Stover, E., Beattie, G.A.C., 2013b. Evaluation of management programs for protecting young citrus plantings from huanglongbing. HortScience. 48, 330-337.

Hussain, M.A., Nath, D., 1927. The citrus psylla (Diaphorina citri, Kuw.) [Psyllidae: Homoptera]. Memoirs of the Department of Agriculture in India, Entomological Series 10: 1-27.

Lapointe, S.L., Stelinski, L.L., Robinson, R.D., 2011. A novel pheromone dispenser for mating disruption of the leafminer Phyllocnistis citrella (Lepidoptera: Gracillariidae). Journal of Economic Entomology 104, 540-547.

Lv, H.N., Guo, XY., Tu, PF., Jiang, Y., 2013. Comparative analysis of the essential oil composition of Murraya paniculata and M. exotica. Natural Product Communications 8, 1473-1475.

Mann, R.S., Tiwari, S., Smoot, J.M., Rouseff, R.L., Stelinski, L.L., 2012. Repellency and toxicity of plant-based essential oils and their constituents against Diaphorina citri Kuwayama (Hemiptera: Psyllidae). J. Appl. Entomol. 136, p. 87-96.

Onagbola, E.O., Rouseff, R.L., Smoot, J.M., Stelinski, L.L., 2011. Guava leaf volatiles and dimethyl disulphide inhibit response of Diaphorina citri Kuwayama to host plant volatiles.

Patt, J.M., Sétamou, M., 2010. Responses of the Asian citrus psyllid to volatiles emitted by the flushing shoots of its Rutaceous host plants. Environ. Entomol. 39, 618-624. 
Raina, V.K., Verma, S.C., Dhawan, S., Khan, M., Ramesh, S., Singh, S.C., Yadav, A., Srivastava S.K., 2006. Essential oil composition of Murraya exótica from the plains of northern India. Flavour and Fragrance Journal, 21, 140-142

340 Robbins, P.S., Alessandro, R.T., Stelinski, L.L., Lapointe, S., 2012. Volatile profiles of young 341 leaves of Rutaceae spp. varying in susceptibility to the Asian citrus psyllid (Hemiptera: 342 Psyllidae). Florida Entomologist, 95, 774-776.

343 Rouseff, R.L., Onagbola, E.O., Smoot, J.M., Stelinski, L.L., 2008. Sulfur volatiles in guava 344 (Psidium guajava L.) leaves: possible defense mechanism. Journal of Agricultural and Food $345 \quad$ Chemistry 56, 8905-8910.

346 Sá, V.A., Fernandes, M.G., 2015. Spatial distribution of nymphs of Trizoida limbata Enderlein, 3471918 (Hemiptera: Triozidae) in guava orchards. Journal of Agricultural Science 7, 41-54.

348 Wenninger, E.J., Stelinski, L.L., Hall, D.G., 2008. Behavioral evidence for a female-produced sex 349 attractant in Diaphorina citri. Entomologia Experimentalis et Applicata. 128, 450-459. 350 Zaka, S.M., Zeng, X, Holford, P., Beattie, G.A.C., 2010. Repellent effect of guava leaf volatiles on 351 settlement of adults of citrus psylla, Diaphorina citri Kuwayama, on citrus. Insect Science. 17, 352 39-45. 
353 Fig. 1. Mortality of adult Diaphorina citri over a ten day period when they were caged without a 354 plant compared to mortality of adults caged with one of the following plants: Psidium guajava 355 'Thai White', P. guajava 'Pink' or citrus. Fit of the logistic model to the different treatments was 356 as follows. Alone: $r^{2}=0.99, F=1,509, P=<0.0001$. 'Thai White': $r^{2}=0.99, F=489, P=$ $357<0.0001$. 'Pink': $r^{2}=0.99, F=735, P=<0.0001$. Citrus: $r^{2}=0.83, F=52, P=<0.0001$. Refer to 358 Table 6 for results of slope comparisons based on logistic regression. 
Table 1

Volatile composition of young and mature leaves of varieties of Psidium guajava L.

\begin{tabular}{|c|c|c|c|c|c|c|c|}
\hline \multirow[b]{2}{*}{ Constituents } & \multirow[b]{2}{*}{$\begin{array}{c}\mathrm{RI}^{\mathrm{a}} \\
\text { (calc.) }\end{array}$} & \multirow[b]{2}{*}{$\begin{array}{l}\mathrm{RI}^{\mathrm{b}} \\
\text { (lit.) }\end{array}$} & \multicolumn{5}{|c|}{ Peak area $(\%)$} \\
\hline & & & 'J3' & 'Thailand' & 'Paluma' & $\begin{array}{l}\text { 'Pedro } \\
\text { sato' }\end{array}$ & $\begin{array}{l}\text { 'Sec } \\
\text { XXI' }\end{array}$ \\
\hline$\alpha$-Pinene & 940 & 939 & 7.20 & - & - & - & - \\
\hline Benzaldehyde & 961 & 960 & - & 0.50 & - & - & 0.59 \\
\hline Limonene & 1030 & 1029 & 22.59 & 0.53 & - & - & 0.22 \\
\hline 1,8-Cineole & 1035 & 1031 & - & 0.61 & - & 1.98 & 2.85 \\
\hline (Z)- $\beta$-Ocimene & 1040 & 1037 & 3.36 & 0.17 & - & 0.94 & 0.89 \\
\hline$\delta$-Elemene & 1339 & 1038 & - & 0.10 & - & - & - \\
\hline$\alpha$-Cubebene & 1350 & 1351 & - & 0.18 & - & - & - \\
\hline$\alpha$-Copaene & 1379 & 1377 & 1.13 & 4.17 & 2.48 & 5.16 & 0.25 \\
\hline Isocaryophyllene & 1406 & 1408 & - & 0.21 & - & - & 0.06 \\
\hline$\beta$-Caryophyllene & 1422 & 1419 & 20.54 & 33.14 & 45.56 & 30.10 & 21.93 \\
\hline$\alpha$-Guaiene & 1438 & 1440 & - & 3.17 & - & - & - \\
\hline Aromadendrene & 1443 & 1441 & 1.45 & - & 4.28 & - & - \\
\hline$\alpha$-humulene & 1458 & 1455 & 2.70 & 5.74 & 6.17 & 6.39 & 3.86 \\
\hline Allo-aromadrendene & 1460 & 1460 & - & 1.47 & - & - & - \\
\hline 9-epi-(E)-Caryophyllene & 1467 & 1466 & 0.75 & - & - & - & - \\
\hline Drima-7,9-diene & 1477 & 1473 & - & - & - & 0.35 & 0.36 \\
\hline$\beta$-Chamigrene & 1477 & 1478 & - & - & - & - & 1.81 \\
\hline$\gamma$-Muurolene & 1477 & 1480 & - & 0.47 & - & - & - \\
\hline$\gamma$-Gurjunene & 1481 & 1480 & 0.62 & - & - & 1.73 & - \\
\hline Germacrene D & 1482 & 1485 & - & - & 1.16 & - & - \\
\hline$\beta$-selinene & 1490 & 1490 & 2.34 & 0.64 & 12.87 & 18.92 & 15.64 \\
\hline$\gamma$-amorphene & 1493 & 1496 & - & 0.20 & - & - & - \\
\hline$\alpha$-Selinene & 1498 & 1498 & 2.57 & 0.71 & 13.19 & 15.02 & 12.87 \\
\hline $\mathrm{Ni}$ & 1501 & - & - & 0.85 & - & - & - \\
\hline (E,E)- $\alpha$-farnesene & 1506 & 1506 & 2.45 & - & - & - & - \\
\hline$\beta$-Bisabolene & 1507 & 1506 & - & 0.43 & - & - & - \\
\hline $\mathrm{Ni}$ & 1512 & - & 1.93 & - & - & - & - \\
\hline$\gamma$-Cadinene & 1513 & 1514 & 1.19 & 0.31 & - & - & - \\
\hline 7-epi- $\alpha$-Selinene & 1515 & 1522 & - & - & - & - & 0.43 \\
\hline $\mathrm{Ni}$ & 1519 & - & - & - & - & 0.35 & \\
\hline$\delta$-Cadinene & 1525 & 1523 & 2.31 & - & 1.55 & 1.54 & 0.43 \\
\hline trans-Cadina-1,4-diene & 1530 & 1535 & - & 1.61 & - & - & - \\
\hline (E)- $\gamma$-Bisabolene & 1535 & 1531 & 0.21 & - & - & - & - \\
\hline $\mathrm{Ni}$ & 1539 & - & - & - & - & 0.36 & - \\
\hline $\mathrm{Ni}$ & 1551 & - & - & - & - & - & 0.61 \\
\hline $\mathrm{Ni}$ & 1559 & - & - & 1.21 & - & - & - \\
\hline (E)-Nerolidol & 1563 & 1563 & 18.50 & 17.03 & - & - & 4.30 \\
\hline Caryophyllenyl alcohol & 1571 & 1572 & - & - & 0.64 & - & 0.53 \\
\hline Spathulenol & 1581 & 1578 & - & 2.43 & - & - & - \\
\hline Caryophyllene oxide & 1587 & 1583 & - & 4.01 & - & 1.41 & 5.08 \\
\hline Globulol & 1587 & 1585 & - & 5.84 & - & - & - \\
\hline $\mathrm{Ni}$ & 1592 & - & 2.20 & - & - & - & - \\
\hline Viridiflorol & 1596 & 1593 & - & 1.26 & 5.44 & 1.90 & - \\
\hline $\mathrm{Ni}$ & 1606 & - & - & 2.68 & - & - & - \\
\hline Humulene epoxide II & 1611 & 1608 & - & - & - & - & 0.50 \\
\hline $\mathrm{Ni}$ & 1615 & - & - & - & - & - & 1.59 \\
\hline $\mathrm{Ni}$ & 1618 & - & 0.29 & - & - & - & 0.46 \\
\hline
\end{tabular}


Table 1, continued.

\begin{tabular}{|c|c|c|c|c|c|c|c|}
\hline \multirow[b]{2}{*}{ Constituents } & \multirow[b]{2}{*}{$\begin{array}{c}\mathrm{RI}^{\mathrm{a}} \\
\text { (calc.) }\end{array}$} & \multirow[b]{2}{*}{$\begin{array}{l}\mathrm{RI}^{\mathrm{b}} \\
\text { (lit.) }\end{array}$} & \multicolumn{5}{|c|}{ Peak area $(\%)$} \\
\hline & & & 'J3' & 'Thailand' & 'Paluma' & $\begin{array}{l}\text { 'Pedro } \\
\text { sato' }\end{array}$ & $\begin{array}{l}\text { 'Sec } \\
\text { XXI' }\end{array}$ \\
\hline $\mathrm{Ni}$ & 1621 & - & - & - & - & 1.27 & - \\
\hline $\mathrm{Ni}$ & 1623 & - & - & - & 0.41 & - & 0.35 \\
\hline 1-epi-cubenol & 1628 & 1629 & 0.75 & 2.11 & 0.66 & 1.25 & - \\
\hline $\mathrm{Ni}$ & 1629 & - & - & - & - & - & 1.25 \\
\hline cis-Cadin-4-en-7-ol & 1633 & 1637 & - & - & - & 0.72 & - \\
\hline Caryophylla-4,8-dien-5 $\beta$-ol & 1638 & 1641 & - & - & - & - & 6.82 \\
\hline$\alpha$-Muurolol & 1641 & 1646 & - & 1.95 & - & - & - \\
\hline Caryophylla-4,8-dien-5 $\alpha$-ol & 1643 & 1641 & - & - & - & 0.72 & 1.45 \\
\hline Cubenol & 1649 & 1647 & - & 1.29 & - & 0.40 & - \\
\hline $\mathrm{Ni}$ & 1651 & - & - & - & - & 0.39 & - \\
\hline Selin-11-en-4 $\alpha$-ol & 1660 & 1660 & 2.35 & - & 5.59 & 9.10 & 13.61 \\
\hline $\mathrm{Ni}$ & 1667 & - & - & - & - & - & 0.70 \\
\hline $\mathrm{Ni}$ & 1683 & - & - & - & - & - & 0.56 \\
\hline Total & & & 97.43 & 95.63 & 100 & 100 & 99.41 \\
\hline
\end{tabular}

${ }^{\mathrm{a}} \mathrm{RI}$ (calc.) = retention indices on DB-5 column.

${ }^{\mathrm{b}} \mathrm{RI}$ (lit.) = retention indices according to the literature.

$\mathrm{Ni}=$ unidentified compounds; - = not observed. 
Table 2

Percentage of each chemical group present in guava oil from each of five Brazilian guava cultivars.

\begin{tabular}{llllll}
\hline \multirow{2}{*}{ Chemical Group } & \multicolumn{3}{l}{ Guava cultivar } \\
\cline { 2 - 6 } & 'J3' & $\begin{array}{l}\text { 'Pedro } \\
\text { Sato' }\end{array}$ & $\begin{array}{l}\text { 'Século } \\
\text { XXI' }\end{array}$ & 'Thailand' & 'Paluma' \\
\hline Monoterpenes & 33.2 & 0.9 & 1.1 & 0.7 & 0.0 \\
Oxygenated Monoterpenes & 0.0 & 2.0 & 2.9 & 0.6 & 0.0 \\
Sesquiterpenes & 38.3 & 79.2 & 57.6 & 52.6 & 87.3 \\
Oxygenated Sesquiterpenes & 21.6 & 15.5 & 32.3 & 35.9 & 12.3 \\
Benzenoids and other compounds & 4.4 & 2.4 & 5.5 & 5.9 & 0.4 \\
\hline Totals & 97.4 & 100.0 & 99.4 & 95.6 & 100.0 \\
\hline
\end{tabular}




\section{Table 3}

Location of adult Asian citrus psyllids $24 \mathrm{~h}$ after being introduced into a cage with free choice to move into one of two assay vials, one with Murraya exotica flush or one with M. exotica flush and guava oil. Guava oil was obtained from five different cultivars. Means followed by same letter (lowercase vertically or uppercase horizontally) are not significantly different (Tukey's test, $P<0.05$ ), analyses on arcsine-transformed percentages, raw mean percentages presented. (SMD: significance minimum difference; VC: variation coefficient).

\begin{tabular}{|c|c|c|c|c|c|c|}
\hline \multirow[b]{2}{*}{$\begin{array}{l}\text { Guava cultivar } \\
\text { oil treatment }\end{array}$} & \multicolumn{3}{|c|}{$\begin{array}{c}\text { Mean percentage of psyllids at the indicated } \\
\text { location }\end{array}$} & \multirow[b]{2}{*}{$\begin{array}{c}F_{2,18} \\
\text { value }\end{array}$} & \multirow[b]{2}{*}{ SMD } & \multirow[b]{2}{*}{$\mathrm{VC} \%$} \\
\hline & Not in a vial & $\begin{array}{l}\text { In the vial with } \\
\text { only } \\
\text { Murraya flush }\end{array}$ & $\begin{array}{l}\text { In the vial } \\
\text { with } \\
\text { Murraya } \\
\text { flush + oil }\end{array}$ & & & \\
\hline 'J3' & 21 a B & 64 a A & $15 \mathrm{~b} \mathrm{~B}$ & $44.84 * *$ & 9.19 & 23.79 \\
\hline 'Pedro Sato' & 28 a B & 49 bc A & $23 \mathrm{~b} \mathrm{~B}$ & $25.02 * *$ & 5.98 & 15.02 \\
\hline 'Século XXI' & 28 a B & $52 \mathrm{~b} \mathrm{~A}$ & $20 \mathrm{~b} \mathrm{~B}$ & $25.49 * *$ & 7.26 & 18.32 \\
\hline 'Thailand' & 26 a B & $50 \mathrm{~b} \mathrm{~A}$ & $24 \mathrm{~b} \mathrm{~B}$ & $22.29 * *$ & 6.74 & 16.96 \\
\hline 'Paluma' & 25 a B & $54 \mathrm{ab} A$ & $21 \mathrm{~b} \mathrm{~B}$ & $22.78 * *$ & 8.37 & 21.14 \\
\hline Control (no oil) & 24 a B & $37 \mathrm{c} \mathrm{A}$ & 39 a A & $3.94 *$ & 9.78 & 24.58 \\
\hline$F_{2,54}$ value & $1.34 \mathrm{~ns}$ & $9.70 * *$ & $9.63 * *$ & & & \\
\hline SMD & 8.66 & 6.92 & 7.24 & & & \\
\hline $\mathrm{VC} \%$ & 22.04 & 11.49 & 19.21 & & & \\
\hline
\end{tabular}




\section{Table 4}

Location of adult Diaphorina citri $24 \mathrm{~h}$ after being introduced into a cage with free choice to move into one of two assay vials, one with Murraya exotica flush or one with either M. exotica flush by itself (cage 1 treatment), M. exotica flush with 'Pink' guava flush (cage 2 treatment), or $M$. exotica flush with a mature 'Pink' guava leaf (cage 3 treatment). Means followed by same letter ((lowercase vertically or uppercase horizontally) are not significantly different (Tukey's test, $P<0.05$ ), analyses on transformed percentages, raw mean percentages presented. (SMD: significance minimum difference; VC: variation coefficient).

\begin{tabular}{|c|c|c|c|c|c|c|}
\hline \multirow[b]{2}{*}{ Treatment } & \multicolumn{3}{|c|}{$\begin{array}{l}\text { Mean percentage of psyllids at the indicated } \\
\text { location }\end{array}$} & \multirow[b]{2}{*}{$\begin{array}{l}F_{2,30} \\
\text { value }\end{array}$} & \multirow[b]{2}{*}{ SMD } & \multirow[b]{2}{*}{$\mathrm{VC} \%$} \\
\hline & $\begin{array}{l}\text { Not in a } \\
\text { vial }\end{array}$ & $\begin{array}{l}\text { In the vial } \\
\text { with only } \\
\text { Murraya } \\
\text { flush }\end{array}$ & $\begin{array}{l}\text { In the vial with } \\
\text { only Murraya } \\
\text { flush, Murraya } \\
\text { flush with guava } \\
\text { flush, or Murraya } \\
\text { flush with a } \\
\text { mature guava leaf }\end{array}$ & & & \\
\hline Cage 1 (no guava) & $21 \mathrm{a} \mathrm{B}$ & 41 a $\mathrm{A}$ & 38 a A & $6.02 * *$ & 9.86 & 32.86 \\
\hline $\begin{array}{l}\text { Cage } 2 \text { (guava } \\
\text { flush) }\end{array}$ & 32 a $\mathrm{A}$ & 41 a $\mathrm{A}$ & $27 \mathrm{ab} A$ & $1.80 \mathrm{~ns}$ & 10.75 & 35.74 \\
\hline $\begin{array}{l}\text { Cage } 3 \text { (mature } \\
\text { guava leaf) }\end{array}$ & 29 a B & 47 a $\mathrm{A}$ & $24 \mathrm{~b} \mathrm{~B}$ & $6.75 * *$ & 10.01 & 33.26 \\
\hline$F_{2,45}$ value & $2.96 \mathrm{~ns}$ & $0.72 \mathrm{~ns}$ & $3.31 *$ & & & \\
\hline SMD & 7.52 & 8.75 & 8.38 & & & \\
\hline $\mathrm{VC} \%$ & 28.50 & 25.18 & 30.24 & & & \\
\hline
\end{tabular}




\section{Table 5}

Location of adult Asian citrus psyllids $24 \mathrm{~h}$ after being introduced into a cage with free choice to move into one of two assay vials, one with Murraya exotica flush or one with either M. exotica flush by itself (cage 1 treatment), $M$. exotica flush with 'Thai White' guava flush (cage 2 treatment), or M. exotica flush with a mature 'Thai White' guava leaf (cage 3 treatment). Means followed by same letter (lowercase vertically or uppercase horizontally) are not significantly different (Tukey's test, $P<0.05$ ), analyses on transformed percentages, raw mean percentages presented. (SMD: significance minimum difference; VC: variation coefficient).

\begin{tabular}{|c|c|c|c|c|c|c|}
\hline \multirow[b]{3}{*}{ Treatment } & \multicolumn{3}{|c|}{$\begin{array}{l}\text { Mean percentage of psyllids at the } \\
\text { indicated location }\end{array}$} & \multirow[b]{3}{*}{$\begin{array}{c}F_{2,30} \\
\text { value }\end{array}$} & \multirow[b]{3}{*}{ SMD } & \multirow[b]{3}{*}{$\mathrm{VC} \%$} \\
\hline & & $\begin{array}{l}\text { In the } \\
\text { vial with } \\
\text { only }\end{array}$ & $\begin{array}{l}\text { In the vial with only } \\
\text { Murraya flush, } \\
\text { Murraya flush with } \\
\text { guava flush, or }\end{array}$ & & & \\
\hline & $\begin{array}{l}\text { Not in a } \\
\text { vial }\end{array}$ & $\begin{array}{l}\text { Murraya } \\
\text { flush }\end{array}$ & $\begin{array}{l}\text { Murraya flush with } \\
\text { a mature guava leaf }\end{array}$ & & & \\
\hline Cage 1 (no guava) & 25 a B & $36 \mathrm{~b} \mathrm{AB}$ & 39 a $\mathrm{A}$ & $6.14 * *$ & 8.00 & 26.47 \\
\hline $\begin{array}{l}\text { Cage } 2 \text { (guava } \\
\text { flush) }\end{array}$ & $14 \mathrm{~b} \mathrm{~B}$ & $37 \mathrm{~b} \mathrm{~A}$ & 50 a $\mathrm{A}$ & $17.97 * *$ & 10.23 & 34.55 \\
\hline $\begin{array}{l}\text { Cage } 3 \text { (mature } \\
\text { guava leaf) }\end{array}$ & 26 a B & 48 a A & $25 \mathrm{~b} \mathrm{~B}$ & $11.88 * *$ & 7.38 & 24.38 \\
\hline$F_{2,45}$ value & $6.49 * *$ & $4.29 *$ & $15.19 * *$ & & & \\
\hline SMD & 7.05 & 7.03 & 6.79 & & & \\
\hline $\mathrm{VC} \%$ & 30.77 & 21.42 & 20.56 & & & \\
\hline
\end{tabular}




\section{Table 6}

Location of adult Asian citrus psyllids $24 \mathrm{~h}$ after being introduced into a cage with free choice to move into one of two assay vials, one with Murraya exotica flush by itself and one with $M$.

exotica flush plus guava. A young guava flush shoot was used in one set of assays and a mature guava leaf was used in a second set of assays. Two guava cultivars were studied, 'Pink' and

'Thai White'. Means followed by same letter (lowercase vertically or uppercase horizontally) are not significantly different (Tukey's test, $P<0.05$ ), analyses on transformed percentages, raw

mean percentages presented. (SMD: significance minimum difference; VC: variation coefficient).

\begin{tabular}{|c|c|c|c|c|c|c|c|}
\hline \multirow[b]{3}{*}{ Vial contents } & \multicolumn{4}{|c|}{$\begin{array}{c}\text { Mean percentage of psyllids at the indicated } \\
\text { location }\end{array}$} & \multirow[b]{3}{*}{$\begin{array}{l}F_{1,60} \\
\text { value }\end{array}$} & \multirow[b]{3}{*}{ SMD } & \multirow[b]{3}{*}{$\mathrm{VC} \%$} \\
\hline & \multicolumn{2}{|c|}{ Guava flush } & \multicolumn{2}{|c|}{ Guava mature leaf } & & & \\
\hline & 'Pink' & $\begin{array}{l}\text { 'Thai } \\
\text { White' }\end{array}$ & 'Pink' & $\begin{array}{l}\text { 'Thai } \\
\text { White' }\end{array}$ & & & \\
\hline $\begin{array}{l}\text { Murraya flush } \\
\text { alone }\end{array}$ & 66 a B & 71 a B & 81 a $\mathrm{AB}$ & 93 a $\mathrm{A}$ & $8.10 * *$ & 14.16 & 23.15 \\
\hline $\begin{array}{l}\text { Murraya flush } \\
\text { plus guava }\end{array}$ & $34 \mathrm{~b} \mathrm{~A}$ & $29 \mathrm{~b} \mathrm{~A}$ & $19 \mathrm{~b} \mathrm{AB}$ & $7 \mathrm{~b} \mathrm{~B}$ & $8.10 * *$ & 14.16 & 61.63 \\
\hline$F_{3,15}$ & $5.06^{*}$ & $37.16 * *$ & $7.92 *$ & $215.20 * *$ & & & \\
\hline SMD & 21.92 & 8.85 & 15.38 & 9.79 & & & \\
\hline $\mathrm{VC} \%$ & 64.88 & 27.22 & 45.42 & 30.12 & & & \\
\hline
\end{tabular}




\section{Table 7}

Mortality curves for adult Asian citrus psyllid confined in cages with 'Thai White' guava, 'Pink' guava, or Citrus macrophylla plants or without plant material, comparison of slopes $\left(\beta_{1}\right)$ from logistic-transformed curves of psyllid mortality. Refer to Fig. 1 for an overview of the curves.

\begin{tabular}{|c|c|c|c|c|c|c|}
\hline \multirow[t]{2}{*}{ Contents of cage } & \multirow{2}{*}{$\begin{array}{l}\text { Regression } \\
\text { slope }\left(\beta_{1}\right)\end{array}$} & \multirow{2}{*}{$\begin{array}{l}\beta_{1} \\
\text { standard } \\
\text { error }\end{array}$} & \multicolumn{4}{|c|}{ Student's $t$-value } \\
\hline & & & $\mathrm{N}$ & $\begin{array}{l}\text { No plant } \\
\text { material }\end{array}$ & $\begin{array}{l}\text { 'Thai White' } \\
\text { guava }\end{array}$ & $\begin{array}{l}\text { 'Pink' } \\
\text { guava }\end{array}$ \\
\hline No plant material & 5.323482 & 0.869062 & 11 & & & \\
\hline 'Thai White' guava plant & 3.722321 & 1.051161 & 9 & $-8.7928^{a}$ & & \\
\hline 'Pink' guava plant & 2.910177 & 1.087584 & 8 & $-11.0438^{a}$ & $-22.2973^{a}$ & \\
\hline $\begin{array}{l}\text { Citrus plant } \\
{ }^{\mathrm{a}} P=<0.0001 .{ }^{\mathrm{b}} P=0.002 .\end{array}$ & $\begin{array}{l}0.56281 \\
{ }^{c} P=0.015\end{array}$ & 0.305311 & 5 & $8.4446^{a}$ & $4.2361^{b}$ & $3.0007^{c}$ \\
\hline
\end{tabular}


Fig. 1.

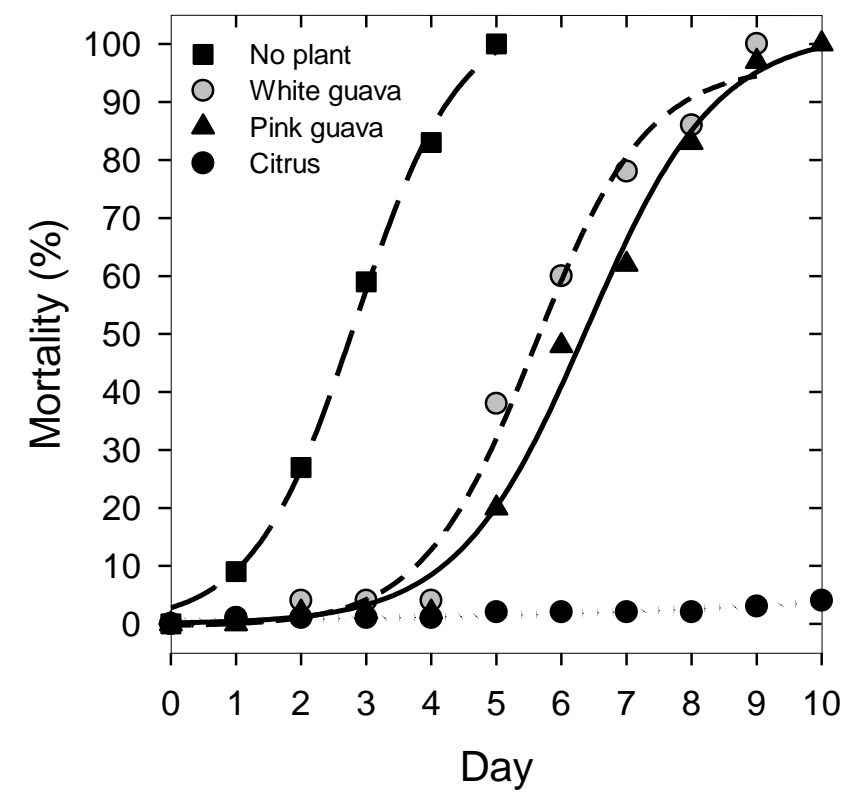

